\title{
Insulin-like growth factor I gene polymorphism associated with growth and carcass traits in Thai synthetic chickens
}

\author{
N. Promwatee ${ }^{1,3}$, B. Laopaiboon ${ }^{2}$, T. Vongpralub ${ }^{1,2}$, Y. Phasuk $^{1,2}$, \\ S. Kunhareang ${ }^{1,2}$, W. Boonkum ${ }^{1,2}$ and M. Duangjinda ${ }^{1,2,3}$ \\ ${ }^{1}$ Department of Animal Science, Khon Kaen University, Khon Kaen, Thailand \\ ${ }^{2}$ Research and Development Network Center for Animal Breeding \\ (Native Chicken), Khon Kaen University, Khon Kaen, Thailand \\ ${ }^{3}$ Center of Excellence on Agricultural Biotechnology (AG-BIO/PERDO-CHE), \\ Bangkok, Thailand
}

Corresponding author: M. Duangjinda

E-mail:monchai@kku.ac.th

Genet. Mol. Res. 12 (4): 4332-4341 (2013)

Received July 31, 2012

Accepted December 13, 2012

Published March 15, 2013

DOI http://dx.doi.org/10.4238/2013.March.15.6

\begin{abstract}
Four Thai synthetic chicken lines (Kaen Thong, Khai Mook Esarn, Soi Nin, and Soi Pet) originated from Thai native and exotic commercial chickens were evaluated for their growth and carcass traits with the purpose of developing a Thai broiler breeding program. Insulinlike growth factor I $(I G F-I)$ gene is known to play an important role in growth, proliferation and differentiation. Consequently, we investigated the possibility of using the $I G F-I$ gene for marker-assisted selection in Thai synthetic chickens. We looked for variations in the $I G F-I$ gene and studied their association with growth and carcass traits; 1046 chickens were genotyped using PCR-RFLP methods. A general linear model was used to analyze associations of the $I G F-I$ polymorphism with growth and carcass traits. Kaen Thong, Khai Mook Esarn, and Soi Nin chickens were found to carry similar frequencies of alleles A and C (0.40-0.60), while Soi Pet chickens had high frequencies of allele $\mathrm{C}(0.75)$. The $I G F-I$ gene was significantly associated with some growth traits (body weight at
\end{abstract}


hatching, and at $4,8,12$, and 14 weeks of age; average daily gain during 0-12 and 0-14 weeks of age) in all synthetic chickens. Carcass traits (the percentage of dressing and pectoralis major) were significantly different only in Khai Mook Esarn chickens. We conclude that $I G F-I$ can be used as a marker gene for the selection of growth and carcass traits of synthetic chickens in a marker-assisted selection program.

Key words: Thai native chicken; Synthetic chicken; IGF-I; PCR-RFLP; Growth traits; Pectoralis major

\section{INTRODUCTION}

Poultry production and consumption in Thailand have greatly increased over the past few decades. Thai consumers prefer meat from Thai native chicken or Thai native crossbred, since they have good meat texture, low cholesterol content, and good taste compared to commercial broilers (Wattanachant et al., 2004; Jaturasitha et al., 2008). Many countries throughout the world have imported grandparent and parent stock of broiler chickens from a few large commercial broiler companies such as Cobb, Aviagen, and Hubbard. Instead of developing a terminal cross for sustainable use, the Research and Development Network Center for Animal Breeding (Native Chicken), Khon Kaen University, Thailand, has developed four Thai synthetic chicken lines: Kaen Thong (KT), Khai Mook Esarn (ME), Soi Nin (SN), and Soi Pet (SP). Under four generations of inter se and intensive selection for higher growth rate, these Thai synthetic chickens have demonstrated future potential for development as Thai broilers.

Growth and carcass traits are of primary concern in breeding programs because they are economically important traits in poultry. These traits are under complex genetic controls; and molecular markers for growth may contribute to more efficient selection for these traits (Li et al., 2006). Marker-assisted selection may increase selection efficiency and improve production performance. Recently, the candidate gene approach has become a powerful technique for genetic improvement (Zhu and Zhao, 2007).

One of the major hormones required to support normal growth and muscle development is insulin-like growth factor I (IGF-I) (Scanes, 2009). IGF-I is a complex system of peptide hormones that bind to the IGF-I receptor (IGFIR) to activate their intrinsic tyrosine kinase domain activities (Denley et al., 2005). Biological responses have effects on cell growth, proliferation, differentiation, and survival against apoptosis (Khandwala et al., 2000; Pollak et al., 2004). For example, the $I G F-I$ gene can influence growth rate, body composition and lipid metabolism in poultry (McMurtry, 1998). The IGF-I gene in chickens is composed of four exons and three introns, spanning more than $50 \mathrm{~kb}$ on chromosome 1 (Kajimoto and Rotwein, 1991). The predominant source of IGF-I is the liver and some other tissues, including muscle, brain and kidney (Barton, 2006). Moreover, plasma concentration of chicken IGF-I is higher in genetic lines selected for high growth rate than in slower growing lines (Scanes et al., 1989). Amills et al. (2003) reported that polymorphism in the promoter region was associated with growth rate and feed efficiency. Meanwhile, Zhou et al. (2005) showed that polymorphism of the $I G F-I$ gene in the promoter and 5'-untranslated region (5'-UTR) was associated with growth and carcass traits. Also, Bian et al. (2008) reported that haplotypes based on three IGF-I polymorphisms (5'-flanking, exon 3, and 3'-flanking regions) were associated with body weight (BW) traits. For the Thai native chicken population, Promwatee 
and Duanginda (2010) found that polymorphism of the $I G F-I$ gene at 5'-UTR was associated with body weight. As a result, the $I G F-I$ gene could be used as a positional candidate gene for growth and carcass traits. Although numerous population studies have focused on pure or F1 and F2 chickens, the specific effects of the $I G F-I$ gene on synthetic chicken growth and carcass traits have not been reported until now.

Consequently, the purpose of the present study was to investigate the possibility of using the $I G F-I$ gene at the $5^{\prime}$-UTR for marker-assisted selection in 4 Thai synthetic chicken lines by: 1) studying the variation or genotype and allele frequencies of the $I G F-I$ gene; and 2) studying the associations of $I G F-I$ gene polymorphism with growth and carcass traits.

\section{MATERIAL AND METHODS}

\section{Chicken populations and traits}

A total of 1046 chickens from four Thai synthetic chicken lines (subsequently termed "synthetic chickens") included KT ( $=220), \mathrm{ME}(\mathrm{N}=302), \mathrm{SN}(\mathrm{N}=283)$, and SP (N = 241). These chickens were developed from four generations of inter se mating between Thai native chickens, known as Chee (sire line) (Dorji et al., 2011), crossed with exotic commercial layers (dam line). Breeding was conducted at the Research and Development Network Center for Animal Breeding (Native Chicken), Khon Kaen University, Thailand. They were fed ad libitum with a commercial layer diet. Phenotypic characteristics of the four synthetic chicken lines are shown in Figure 1 and Table 1. Growth traits were measured for all individuals, including BW at hatch, and at 4, 8, 12, and 14 weeks of age (BW0, BW4, BW8, BW12, and BW14, respectively). The average daily gain (ADG) was calculated during 0-12 (ADG $0-12$ ) and $0-14$ (ADG 0-14) weeks of age, and breast width (BrW) at 14 weeks of age. For the determination of carcass traits, a total of 96 birds ( 24 birds per line) were slaughtered at 14 weeks of age. In each line, chickens were randomly selected based on average BW by sex for each genotype of the $I G F-I$ gene (AA, AC, and CC genotypes, respectively). Carcass traits included dressing percentage, and the percentage of retail cuts: breast (pectoralis major), tenderloin (pectoralis minor), drumstick, wing, and thigh.

\section{Genotyping by PCR-restriction fragment length polymorphism (RFLP) procedure}

Genomic DNA was isolated from blood samples taken at 8 weeks of age (stored with EDTA as an anti-coagulant) using a guanidine hydrochloride/silica gel protocol modified from Goodwin et al. (2007). PCR primers (forward: 5'-TCA AGA GAA GCC CTT CAA GC-3'; reverse: 5'-CAT TGC GCA GGC TCT ATC TG-3') for the chicken IGF-I gene were used (Zhou et al., 2005). PCR was performed in a $10-\mu \mathrm{L}$ volume containing about $1 \mu \mathrm{L} 50 \mathrm{ng}$ genomic DNA, $1 \mu \mathrm{L}$ 10X PCR buffer, $1 \mu \mathrm{L} 2 \mu \mathrm{M}$ primer, $1 \mu \mathrm{L} 1 \mathrm{mM}$ dNTP (Promega, USA), $0.8 \mu \mathrm{L} 25$ $\mathrm{mM} \mathrm{MgCl}{ }_{2}$, and $0.1 \mu \mathrm{L} 5 \mathrm{U}$ Taq DNA polymerase (RBC). PCR amplification was conducted under the following conditions: $5 \mathrm{~min}$ at $95^{\circ} \mathrm{C}$, followed by 35 cycles of $30 \mathrm{~s}$ at $95^{\circ} \mathrm{C}, 30 \mathrm{~s}$ at $68^{\circ} \mathrm{C}$ and $45 \mathrm{~s}$ at $72^{\circ} \mathrm{C}$, and a final extension of $7 \mathrm{~min}$ at $72^{\circ} \mathrm{C}$. Polymorphisms were detected by PCR-RFLP. PCR products $\left(813 \mathrm{bp}\right.$ ) were digested at $37^{\circ} \mathrm{C}$ overnight with $1 \mathrm{U}$ HinfI. The restriction enzyme HinfI produced fragment sizes of 622 and $191 \mathrm{bp}$ for the CC genotype, fragment sizes of 622, 378, 244, and 191 bp for the AC genotype, and fragment sizes of 378, 
244, and $191 \mathrm{bp}$ for the AA genotype. The restriction patterns were visualized by $2 \%$ agarose gel electrophoresis; gels were stained with GelStar ${ }^{\circledR}$ nucleic acid gel stain (Cambrex Bio Science, Rockland, ME, USA). Gels were visualized and photographed using a gel documentation system (Lab Focus, Bangkok, Thailand).
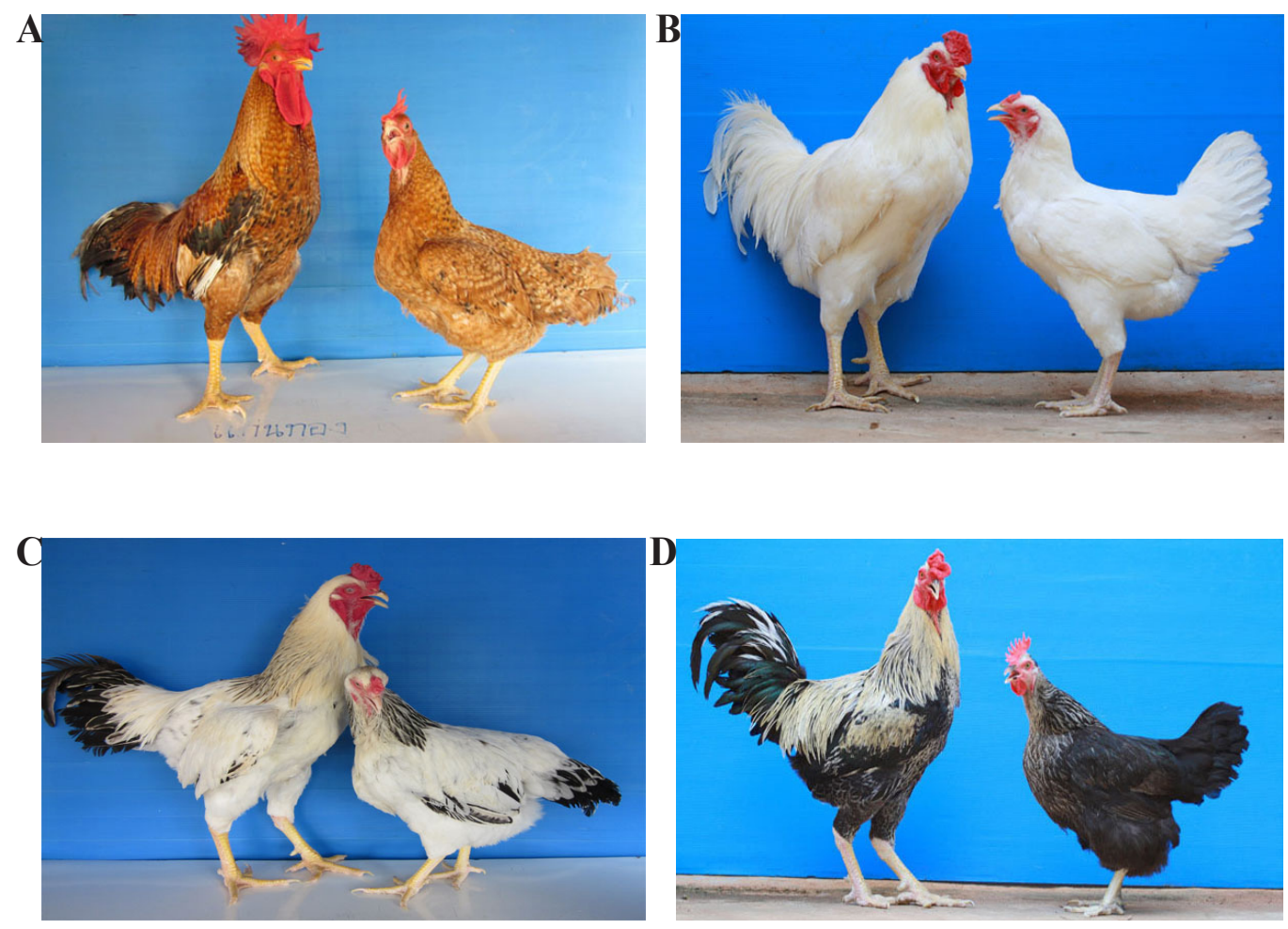

Figure 1. Male (left) and female (right) Thai synthetic chickens. A. Kaen Thong; B. Khai Mook Esarn; C. Soi Nin; D. Soi Pet.

\begin{tabular}{|c|c|c|c|c|}
\hline \multirow[t]{2}{*}{ Lines } & \multicolumn{3}{|c|}{ Morphological features } & \multirow[t]{2}{*}{ Future purpose } \\
\hline & Comb type & Plumage & Shank and beak & \\
\hline KT & Single or pea & Males and females are golden brown & Yellowish & $\begin{array}{l}\text { Develop for dam line or organic } \\
\text { egg production }\end{array}$ \\
\hline ME & Single or pea & Both adults' entire plumage is pearl white & Yellowish & Develop for Thai broilers \\
\hline SN & Single or pea & $\begin{array}{l}\text { Males and females are mainly white on the } \\
\text { body, while the neck and wing are an onyx color }\end{array}$ & Yellowish & $\begin{array}{l}\text { Develop for free range, backyard or } \\
\text { organic chicken, and an alternative } \\
\text { line for Thai crossbred }\end{array}$ \\
\hline SP & Single or pea & $\begin{array}{l}\text { Males are mainly black on the ventral part, with } \\
\text { diamond at the back and neck } \\
\text { Females are usually black with a diamond necklace }\end{array}$ & Yellowish to black & $\begin{array}{l}\text { Develop for free range chicken, and } \\
\text { an alternative line for Thai crossbred }\end{array}$ \\
\hline
\end{tabular}

KT = Kaen Thong; ME = Khai Mook Esarn; SN = Soi Nin; SP = Soi Pet. 


\section{Statistical analysis}

The comparison of growth and carcass traits between Thai synthetic chicken lines by sex was performed using a general linear model:

$$
y_{i j k}=\mu+S_{i}+H_{j}+L_{k}+L_{k} * S_{i}+e_{i j k} \quad \text { (Equation 1) }
$$

in which $y_{i j k}$ is the trait observation, $\mu$ is the overall population mean, $S_{i}$ is the fixed effect of sex, $H_{j}$ is the fixed effect of hatch, $L_{k}$ is the fixed effect of line, and $e_{i j k}$ is the residual random error. Genotypic and allelic frequencies were calculated, and marker-trait association analysis was performed using a general linear model. Phenotypic data were analyzed by the following model:

$$
y_{i j k}=\mu+G_{i}+S_{j}+H_{k}+e_{i j k}
$$

where $y_{\mathrm{ijk}}$ is an observed trait, $\mu$ is the overall population mean, $G_{i}$ is the fixed effect of genotype, $S_{j}$ is the fixed effect of sex, $H_{k}$ is the fixed effect of hatch, and $e_{i j k}$ is the residual random error.

\section{RESULTS AND DISCUSSION}

\section{Growth performance}

A comparison of growth performance for the 4 synthetic chicken lines, differentiated by sex, is provided in Table 2 . Male and female chickens are known to typically exhibit significant differences in growth rate. This was in accordance with the present findings, which showed significant differences in growth rates between male and female synthetic chickens for BW4, BW8, BW12, BW14, BrW, ADG 0-12, and ADG 0-14 $(\mathrm{P}<0.05)$; however, there was no significant difference for $\mathrm{BW} 0(\mathrm{P}>0.05)$. The results indicated that KT had the lowest body weight at 4 to 14 weeks of age, and also the lowest BrW, ADG 0-12 and ADG 0-14 $(\mathrm{P}<0.05)$ when compared with other lines. In contrast, ME, SN and SP showed no significant differences for BW12, BW14, ADG 0-12 and ADG 0-14. Male ME, SN and SP chickens of BW14 weighed about 1532-1561 g, whereas the average body weight of Thai native chickens at 16 weeks of age was $1280 \mathrm{~g}$ (Jaturasitha et al., 2008). Therefore, SN, SP and ME may be appropriate candidates to develop for Thai broiler production. Moreover, a BW14 of around 1100-1500 g could be an appropriate market size: the live weight for marketable chickens is generally considered to be around $1300 \mathrm{~g}$, which is a suitable size for popular traditional dishes such as grilled chicken (kai yang) and spicy soup (tom yam) (Haitook et al., 2003).

Carcass traits of the four synthetic chickens are shown in Table 3. The least square means of wing percentage demonstrated a significant difference $(\mathrm{P}<0.05)$ between KT and the other three lines for both sexes, while the drumstick percentage showed a significant difference only among male chickens. KT had the lowest growth and carcass traits compared to the other three lines; this indicated that the genetic background of these four Thai synthetic chickens may be developed for different purposes in a breeding program. 
Table 2. Least square means by sex for growth traits in four Thai synthetic chicken lines.

\begin{tabular}{|c|c|c|c|c|c|c|c|c|c|c|}
\hline \multirow[t]{2}{*}{ Sex } & \multirow[t]{2}{*}{ Lines/traits } & \multirow[t]{2}{*}{$\mathrm{N}$} & \multicolumn{5}{|c|}{ Body weight (g) } & \multirow{2}{*}{$\begin{array}{l}\mathrm{BrW} \\
(\mathrm{cm})\end{array}$} & \multirow{2}{*}{$\begin{array}{c}\text { ADG 0-12 } \\
\text { (g/day) }\end{array}$} & \multirow{2}{*}{$\begin{array}{c}\text { ADG 0-14 } \\
\text { (g/day) }\end{array}$} \\
\hline & & & BW0 & BW4 & BW8 & BW12 & BW14 & & & \\
\hline \multirow[t]{4}{*}{ Male } & KT & 106 & 34.0 & $197.9^{d}$ & $611.6^{c}$ & $1166.9^{b}$ & $1450.1^{\mathrm{b}}$ & $5.76^{\mathrm{c}}$ & $13.49^{\mathrm{b}}$ & $14.45^{\mathrm{b}}$ \\
\hline & $\mathrm{ME}$ & 163 & 37.8 & $253.9^{\mathrm{a}}$ & $707.7^{\mathrm{a}}$ & $1280.7^{\mathrm{a}}$ & $1561.3^{\mathrm{a}}$ & $6.02^{\mathrm{a}}$ & $14.80^{\mathrm{a}}$ & $15.55^{\mathrm{a}}$ \\
\hline & SN & 119 & 33.8 & $219.1^{\mathrm{c}}$ & $665.6^{\mathrm{b}}$ & $1252.0^{\mathrm{a}}$ & $1532.9^{\mathrm{a}}$ & $5.87^{\mathrm{b}}$ & $14.50^{\mathrm{a}}$ & $15.30^{\mathrm{a}}$ \\
\hline & SP & 117 & 34.6 & $233.7^{b}$ & $687.2^{\mathrm{ab}}$ & $1265.7^{\mathrm{a}}$ & $1551.1^{\mathrm{a}}$ & $5.89^{b}$ & $14.66^{\mathrm{a}}$ & $15.47^{\mathrm{a}}$ \\
\hline SE & & & 0.3 & 3.5 & 9.0 & 15.0 & 17.6 & 0.04 & 0.18 & 0.18 \\
\hline \multirow[t]{4}{*}{ Female } & KT & 114 & 33.6 & $173.2^{\mathrm{c}}$ & $499.2^{\mathrm{c}}$ & $921.9^{\mathrm{b}}$ & $1102.2^{\mathrm{b}}$ & $5.28^{\mathrm{c}}$ & $10.58^{\mathrm{b}}$ & $10.90^{\mathrm{b}}$ \\
\hline & $\mathrm{ME}$ & 139 & 37.3 & $223.6^{\mathrm{a}}$ & $591.3^{\mathrm{a}}$ & $1027.8^{a}$ & $1228.5^{\mathrm{a}}$ & $5.71^{\mathrm{a}}$ & $11.79^{\mathrm{a}}$ & $12.16^{\mathrm{a}}$ \\
\hline & SN & 164 & 33.9 & $201.1^{\mathrm{b}}$ & $565.2^{\mathrm{b}}$ & $1014.0^{\mathrm{a}}$ & $1206.7^{\mathrm{a}}$ & $5.59^{\mathrm{b}}$ & $11.67^{\mathrm{a}}$ & $11.97^{\mathrm{a}}$ \\
\hline & SP & 124 & 34.5 & $214.9^{\mathrm{a}}$ & $594.7^{\mathrm{a}}$ & $1031.3^{\mathrm{a}}$ & $1222.0^{\mathrm{a}}$ & $5.57^{b}$ & $11.87^{\mathrm{a}}$ & $12.12^{\mathrm{a}}$ \\
\hline SE & & & 0.3 & 3.3 & 8.7 & 14.5 & 16.8 & 0.04 & 0.17 & 0.17 \\
\hline
\end{tabular}

a,b,c,d Within a column in each sex with no common superscript are significantly different $(\mathrm{P}<0.05)$. KT $=\mathrm{Kaen}$ Thong; ME = Khai Mook Esarn; SN = Soi Nin; SP = Soi Pet; BW0, BW4, BW8, BW12, and BW14 = body weight at hatch, and at $4,8,12$, and 14 weeks of age, respectively; $\mathrm{BrW}=$ breast width at 14 weeks of age; ADG 0 -12 and $0-14=$ average daily gain during $0-12$ and $0-14$ weeks of age, respectively.

Table 3. Least square means for carcass traits at 14 weeks of age by sex in four Thai synthetic chicken lines.

\begin{tabular}{|c|c|c|c|c|c|c|c|c|}
\hline \multirow[t]{2}{*}{ Sex } & \multirow[t]{2}{*}{ Lines } & \multirow[t]{2}{*}{$\mathrm{N}$} & \multicolumn{6}{|c|}{ Carcass traits $(\%)$} \\
\hline & & & Dressing percentage & Pectoralis major & Pectoralis minor & Wing & Drumstick & Thigh \\
\hline \multirow[t]{4}{*}{ Male } & KT & 12 & 64.25 & 17.73 & 4.65 & $13.89^{b}$ & $17.10^{\mathrm{b}}$ & 20.80 \\
\hline & ME & 12 & 61.89 & 15.93 & 4.45 & $15.13^{\mathrm{a}}$ & $18.40^{\mathrm{a}}$ & 20.43 \\
\hline & SN & 12 & 63.04 & 16.36 & 4.55 & $15.04^{\mathrm{a}}$ & $17.71^{\mathrm{ab}}$ & 20.02 \\
\hline & SP & 12 & 61.87 & 16.67 & 4.37 & $15.14^{\mathrm{a}}$ & $17.69^{\mathrm{ab}}$ & 20.84 \\
\hline SE & & & 0.72 & 0.46 & 0.16 & 0.26 & 0.30 & 0.39 \\
\hline \multirow[t]{4}{*}{ Female } & KT & 12 & 63.24 & 16.71 & 4.82 & $14.31^{\mathrm{b}}$ & 16.22 & 20.51 \\
\hline & ME & 12 & 62.62 & 17.11 & 5.06 & $14.95^{\mathrm{a}}$ & 17.00 & 19.79 \\
\hline & SN & 12 & 62.34 & 17.38 & 5.12 & $14.55^{\mathrm{a}}$ & 16.50 & 19.25 \\
\hline & SP & 12 & 62.42 & 18.29 & 5.07 & $14.46^{\mathrm{a}}$ & 16.47 & 19.68 \\
\hline SE & & & 0.72 & 0.46 & 0.16 & 0.26 & 0.30 & 0.39 \\
\hline
\end{tabular}

${ }^{\mathrm{a}, \mathrm{b}}$ Within a column in each sex with no common superscript are significantly different $(\mathrm{P}<0.05) . \mathrm{KT}=$ Kaen Thong; $\mathrm{ME}=$ Khai Mook Esarn; SN = Soi Nin; SP = Soi Pet. Dressing = carcass weight without visceral organs, head, neck, and shanks on live weight $\mathrm{x} 100$. The percentage of retail cuts on carcass weight without visceral organs, head, neck, and shanks.

\section{Genotype and allele frequencies of the IGF-I gene}

Genotype and allele frequencies of the $I G F-I$ gene in the four synthetic chickens are shown in Table 4. Genotype frequency analysis indicated that the AA genotype was of significantly lower frequency than the AC and CC genotypes in all chicken lines. Allele frequencies showed that allele A was as frequent as allele $\mathrm{C}$ in all lines except for SP; in the SP population, allele $\mathrm{A}(0.25)$ was of lower frequency than allele $\mathrm{C}(0.75)$. The effective allele was allele A because the broiler line had fragment sizes of allele A (Zhou et al., 2005); also, the AA genotype resulted in higher body weight compared to the AC and CC genotypes among Thai native chickens (Promwatee and Duangjinda, 2010). Therefore, allele A of the $I G F-I$ gene could possibly be applied to the four synthetic chicken lines because of its high frequency.

\section{Association of the IGF-I gene polymorphism with growth traits}

The metabolic effects of avian IGF include increased amino acid and glucose uptake 
and the upregulation of DNA and protein synthesis (McMurtry, 1998). We hypothesized that differences in growth patterns would result from the effects of the $I G F-I$ gene. The polymorphic site of the IGF-I gene was located in the promoter region and 5'-UTR, near a putative TATA box, and consisted of one A-to-C substitution (Amills et al., 2003; Zhou et al., 2005). It is noteworthy that the polymorphism of the IGF-I gene is associated with some growth traits in four synthetic chicken lines (Table 5). In the KT population, BW0 was significantly higher only in the AA genotype as compared with the AC and CC genotypes. In the ME population, BW4, BW8, BW12, BW14, ADG $0-12$, and ADG 0-14 were significantly higher in the AA genotype than in the CC genotype. In the $\mathrm{SN}$ population, $\mathrm{BW} 0$ was higher in the AA genotype than in the $\mathrm{AC}$ and $\mathrm{CC}$ genotypes; on the other hand, BW12, BW14, ADG 0-12, and AGD 0-14 were higher in the AA and AC genotypes than in the $\mathrm{CC}$ genotype. In particular, $\mathrm{AA}$ and $\mathrm{AC}$ genotypes demonstrated higher growth rates than did the CC genotype (Table 5). For the SP population, BW0, BW4, BW8, BW12, BW14, ADG 0-12, and ADG 0-14 were significantly higher in the AA genotype than in the $\mathrm{CC}$ genotype. The results of the present study were in accordance with Zhou et al. (2005) and Promwatee and Duangjinda (2010). Moreover, Amills et al. (2003) reported that for the same mutation of the IGF-I gene in two chicken strains of the Black Penedesenca breed, a significant association of $I G F-I$ SNP1 was found for ADG only to 107 days in one strain. Furthermore, the broiler line had fragment sizes of 378, 244 and 191 bp (AA genotype) (Zhou et al., 2005); thus, the AA genotype may result in greater improvement of (marketable) BW. The results from this study indicated that the IGF-I gene was associated with BW and ADG, particularly in three of the four synthetic chicken lines. Therefore, the $I G F-I$ gene is likely a potential marker for use in a marker-assisted selection program. However, further evaluation of the associations between candidate genes and growth traits in other breeds or lines of chickens should be undertaken before this technique can be widely applied in a markerassisted selection program.

Table 4. Genotype and allele frequencies of the $I G F-I$ gene in four Thai synthetic chicken lines.
\begin{tabular}{llccccr}
\hline Lines & $\mathrm{N}$ & \multicolumn{3}{c}{ Genotypes } & & Alleles \\
\cline { 3 - 7 } & & AA & AC & CC & A & C \\
\hline KT & 220 & 0.25 & 0.45 & 0.30 & 0.48 & 0.52 \\
ME & 302 & 0.17 & 0.46 & 0.37 & 0.50 & 0.60 \\
SN & 283 & 0.25 & 0.51 & 0.24 & 0.50 \\
SP & 241 & 0.05 & 0.39 & 0.56 & 0.25 & 0.75 \\
\hline
\end{tabular}

KT = Kaen Thong; $\mathrm{ME}=$ Khai Mook Esarn; $\mathrm{SN}=$ Soi Nin; $\mathrm{SP}=$ Soi Pet.

\section{Association of the $I G F-I$ gene polymorphism with carcass traits}

The $I G F-I$ gene polymorphism was significantly associated with dressing percentage and pectoralis major weight percentage only in the ME population (Table 6). The AA genotype displayed more significant differences than did the CC genotype for both traits $(\mathrm{P}<0.05)$. This study suggests that the use of the $I G F-I$ gene could be valuable for efficient genetic selection for growth in ME chickens in terms of carcass traits. Amills et al. (2003) showed that the substitution $\mathrm{A} \rightarrow \mathrm{C}$ in the promoter region is involved in the suppression of one potential CdxA transcription factor binding site. Moreover, Zhou et al. (2005) reported a higher level of circulating IGF-I protein in the AA genotype compared with the CC genotype because of the SNPs in the promoter region. It is hypothesized that $I G F-I \mathrm{SNP}(\mathrm{A} \rightarrow \mathrm{C})$ polymorphism has an effect on growth and carcass traits by enhancing gene expression. 
Table 5. Least-square means of growth traits by genotype of the $I G F-I$ gene in four synthetic chicken lines.

\begin{tabular}{|c|c|c|c|c|c|c|c|c|}
\hline \multirow[t]{2}{*}{ Lines/traits } & \multicolumn{5}{|c|}{ Body weight (g) } & \multirow{2}{*}{$\begin{array}{l}\mathrm{BrW} \\
(\mathrm{cm})\end{array}$} & \multirow{2}{*}{$\begin{array}{l}\text { ADG 0-12 } \\
\text { (g/day) }\end{array}$} & \multirow{2}{*}{$\begin{array}{c}\text { ADG 0-14 } \\
\text { (g/day) }\end{array}$} \\
\hline & BW0 & BW4 & BW8 & BW12 & BW14 & & & \\
\hline \multicolumn{9}{|l|}{ KT } \\
\hline $\mathrm{AA}(\mathrm{N}=56)$ & $35.10^{\mathrm{a}}$ & 195.75 & 565.11 & 1036.45 & 1255.27 & 5.52 & 11.92 & 12.45 \\
\hline $\mathrm{AC}(\mathrm{N}=98)$ & $33.06^{\mathrm{b}}$ & 182.96 & 561.33 & 1064.08 & 1299.58 & 5.52 & 12.27 & 12.92 \\
\hline $\mathrm{CC}(\mathrm{N}=66)$ & $33.78^{b}$ & 186.88 & 547.32 & 1050.16 & 1292.65 & 5.53 & 12.10 & 12.84 \\
\hline SE & 0.44 & 4.74 & 12.78 & 20.35 & 23.96 & 0.05 & 0.24 & 0.24 \\
\hline \multicolumn{9}{|l|}{ ME } \\
\hline $\mathrm{AA}(\mathrm{N}=51)$ & 37.10 & $246.32^{\mathrm{a}}$ & $668.81^{\mathrm{a}}$ & $1198.00^{\mathrm{a}}$ & $1453.42^{\mathrm{a}}$ & 5.96 & $13.82^{\mathrm{a}}$ & $14.45^{\mathrm{a}}$ \\
\hline $\mathrm{AC}(\mathrm{N}=140)$ & 37.55 & $241.82^{\mathrm{a}}$ & $658.23^{\mathrm{a}}$ & $1161.26^{\mathrm{ab}}$ & $1395.44^{\text {ab }}$ & 5.87 & $13.38^{\mathrm{ab}}$ & $13.86^{\mathrm{ab}}$ \\
\hline $\mathrm{CC}(\mathrm{N}=111)$ & 37.64 & $230.65^{b}$ & $627.54^{b}$ & $1123.19^{\mathrm{b}}$ & $1364.35^{\mathrm{b}}$ & 5.81 & $12.92^{\mathrm{b}}$ & $13.54^{\mathrm{b}}$ \\
\hline SE & 0.31 & 4.3 & 10.42 & 18.59 & 22.09 & 0.05 & 0.22 & 0.23 \\
\hline \multicolumn{9}{|l|}{ SN } \\
\hline $\mathrm{AA}(\mathrm{N}=71)$ & 35.35 & 205.36 & $594.54^{b}$ & $1147.83^{\mathrm{a}}$ & $1389.94^{\mathrm{a}}$ & 5.76 & $13.24^{\mathrm{a}}$ & $13.82^{\mathrm{a}}$ \\
\hline $\mathrm{AC}(\mathrm{N}=143)$ & 33.34 & 213.17 & $628.82^{\mathrm{a}}$ & $1148.65^{\mathrm{a}}$ & $1384.21^{\mathrm{a}}$ & 5.74 & $13.28^{\mathrm{a}}$ & $13.79^{\mathrm{a}}$ \\
\hline $\mathrm{CC}(\mathrm{N}=69)$ & 33.33 & 208.23 & $608.75^{a}$ & $1084.31^{\mathrm{b}}$ & $1319.83^{b}$ & 5.68 & $12.51^{\mathrm{b}}$ & $13.13^{\mathrm{b}}$ \\
\hline SE & 0.41 & 3.87 & 10.03 & 16.05 & 18.61 & 0.04 & 0.19 & 0.19 \\
\hline \multicolumn{9}{|l|}{ SP } \\
\hline $\mathrm{AA}(\mathrm{N}=13)$ & $35.92^{\mathrm{a}}$ & $249.52^{\mathrm{a}}$ & $710.18^{\mathrm{a}}$ & $1254.89^{\mathrm{a}}$ & $1525.47^{\mathrm{a}}$ & 5.95 & $14.51^{\mathrm{a}}$ & $15.20^{\mathrm{a}}$ \\
\hline $\mathrm{AC}(\mathrm{N}=93)$ & $34.31^{\mathrm{b}}$ & $226.41^{b}$ & $660.03^{\mathrm{a}}$ & $1185.46^{\mathrm{a}}$ & $1414.93^{\mathrm{a}}$ & 5.75 & $13.71^{\mathrm{a}}$ & $14.09^{\mathrm{a}}$ \\
\hline $\mathrm{CC}(\mathrm{N}=135)$ & $34.72^{\mathrm{ab}}$ & $220.9^{b}$ & $622.24^{b}$ & $1117.51^{\mathrm{b}}$ & $1359.25^{\mathrm{b}}$ & 5.71 & $12.89^{\mathrm{b}}$ & $13.52^{\mathrm{b}}$ \\
\hline SEM & 0.36 & 5.91 & 15.77 & 25.94 & 30.21 & 0.06 & 0.31 & 0.31 \\
\hline
\end{tabular}

a,b Within a column in each line with no common superscript are significantly different $(\mathrm{P}<0.05)$. For abbreviations, see legend to Table 2 .

Table 6. Least-square means of carcass traits by genotype of the $I G F-I$ gene in four synthetic chicken lines.

\begin{tabular}{|c|c|c|c|c|c|c|}
\hline \multirow[t]{2}{*}{ Lines } & \multicolumn{6}{|c|}{ Carcass traits $(\%)$} \\
\hline & Dressing percentage & Pectoralis major & Pectoralis minor & Wing & Drumstick & Thigh \\
\hline \multicolumn{7}{|l|}{$\overline{\mathrm{KT}}$} \\
\hline $\mathrm{AA}(\mathrm{N}=8)$ & 64.12 & 16.88 & 4.71 & 14.15 & 16.36 & 20.51 \\
\hline $\mathrm{AC}(\mathrm{N}=8)$ & 63.11 & 17.75 & 4.73 & 14.17 & 16.97 & 20.81 \\
\hline $\mathrm{CC}(\mathrm{N}=8)$ & 63.99 & 17.03 & 4.75 & 13.97 & 16.65 & 20.64 \\
\hline SE & 0.65 & 0.54 & 0.10 & 0.31 & 0.27 & 0.51 \\
\hline \multicolumn{7}{|l|}{ ME } \\
\hline $\mathrm{AA}(\mathrm{N}=8)$ & $63.54^{\mathrm{a}}$ & $17.28^{\mathrm{a}}$ & 4.86 & 14.81 & 17.5 & 19.93 \\
\hline $\mathrm{AC}(\mathrm{N}=8)$ & $61.93^{b}$ & $16.95^{\mathrm{a}}$ & 4.62 & 15.12 & 17.4 & 20.51 \\
\hline $\mathrm{CC}(\mathrm{N}=8)$ & $61.52^{\mathrm{b}}$ & $15.45^{\mathrm{b}}$ & 4.78 & 15.18 & 18.15 & 19.81 \\
\hline SE & 0.49 & 0.41 & 0.23 & 0.35 & 0.36 & 0.52 \\
\hline \multicolumn{7}{|l|}{ SN } \\
\hline $\mathrm{AA}(\mathrm{N}=8)$ & 62.91 & 16.46 & 4.84 & 14.63 & 16.84 & 20.06 \\
\hline $\mathrm{AC}(\mathrm{N}=8)$ & 63.29 & 16.92 & 4.97 & 14.64 & 17.37 & 19.96 \\
\hline $\mathrm{CC}(\mathrm{N}=8)$ & 61.86 & 17.23 & 4.69 & 15.10 & 17.10 & 18.88 \\
\hline $\mathrm{SE}$ & 0.64 & 0.66 & 0.26 & 0.25 & 0.28 & 0.35 \\
\hline \multicolumn{7}{|l|}{ SP } \\
\hline $\mathrm{AA}(\mathrm{N}=8)$ & 63.66 & 18.23 & 4.81 & 14.63 & 17.22 & 20.78 \\
\hline $\mathrm{AC}(\mathrm{N}=8)$ & 60.69 & 17.56 & 4.87 & 14.71 & 16.98 & 20.70 \\
\hline $\mathrm{CC}(\mathrm{N}=8)$ & 62.67 & 17.02 & 4.48 & 14.85 & 17.17 & 19.69 \\
\hline $\mathrm{SE}$ & 1.43 & 0.69 & 0.19 & 0.44 & 0.55 & 0.55 \\
\hline
\end{tabular}

${ }_{\mathrm{a}, \mathrm{b}}$ Within a column in each line with no common superscript are significantly different $(\mathrm{P}<0.05)$. KT $=$ Kaen Thong; $\mathrm{ME}=$ Khai Mook Esarn; $\mathrm{SN}=$ Soi Nin; $\mathrm{SP}=$ Soi Pet. Dressing percentage = carcass weight without visceral organs, head, neck, and shanks on live weight x 100. The percentage of retail cuts on carcass weight without visceral organs, head, neck, and shanks.

In general, three strategies for the use of candidate genes in selection are: a) tandem selection, with selection of candidates followed by selection of phenotype or estimated breed- 
ing value (EBV); $b$ ) index selection based on a combination of candidate gene and phenotype or EBV; and c) pre-selection based on a candidate gene (or an index of candidate gene and EBV) at a young age, followed by selection based on an updated EBV at a later age (Dekkers, 2004).

\section{CONCLUSIONS}

KT, ME, and SN chickens have high frequencies of alleles A and C, while SP chickens have high frequencies of allele C. Polymorphism of the $I G F-I$ gene was associated with a certain amount of growth (BW0, BW4, BW8, BW12, BW14, ADG 0-12, and ADG 0-14) in all synthetic chickens $(\mathrm{P}<0.05)$, while carcass traits (dressing and pectoralis major percentages) were significantly different only in ME chickens $(\mathrm{P}<0.05)$. However, polymorphism of the $I G F-I$ gene may be not be appropriate for application as a candidate marker for selecting chicken growth traits in the KT population, due to the fact that only BW0 showed an association. In summary, the IGF-I gene (AA and AC genotypes) could be a genetic locus significantly affecting growth and carcass traits in synthetic chickens.

\section{ACKNOWLEDGMENTS}

Research supported by the Center of Excellence on Agricultural Biotechnology, Science and Technology Postgraduate Education and Research Development Office, Office of the Higher Education Commission, Ministry of Education (AG-BIO/PERDO-CHE), Thailand and Higher Education Research Promotion and National Research University Project of Thailand, Office of the Higher Education Commission, through the Food and Functional Food Research Cluster of Khon Kaen University. We thank the Research and Development Network Center for Animal Breeding (Native Chicken), KKU-TRF, Thailand, for providing samples in this study.

\section{REFERENCES}

Amills M, Jimenez N, Villalba D, Tor M, et al. (2003). Identification of three single nucleotide polymorphisms in the chicken insulin-like growth factor 1 and 2 genes and their associations with growth and feeding traits. Poult. Sci. 82: $1485-1493$.

Barton ER (2006). The ABCs of IGF-I isoforms: impact on muscle hypertrophy and implications for repair. Appl. Physiol. Nutr. Metab. 31: 791-797.

Bian LH, Wang SZ, Wang QG, Zhang S, et al. (2008). Variation at the insulin-like growth factor 1 gene and its association with body weight traits in the chicken. J. Anim. Breed. Genet. 125: 265-270.

Dekkers JC (2004). Commercial application of marker- and gene-assisted selection in livestock: strategies and lessons. $J$. Anim. Sci. 82 (E-Suppl): E313-E328.

Denley A, Cosgrove LJ, Booker GW, Wallace JC, et al. (2005). Molecular interactions of the IGF system. Cytokine Growth Factor Rev. 16: 421-439.

Dorji N, Daungjinda M and Phasuk Y (2011). Genetic characterization of Thai indigenous chickens compared with commercial lines. Trop. Anim. Health Prod. 43: 779-785.

Goodwin W, Linacre A and Hadi S (2007). An Introduction to Forensic Genetics. John Wiley \& Sons Ltd., Chichester.

Haitook T, Tawfik E and Zöbisch M (2003). Options for Native Chicken (Gallus domesticus) Production in Northeastern Thailand. Conference on International Agricultural Research for Development. Deutscher Tropentag 2003, Göttingen, October 8-10, 2003.

Jaturasitha S, Srikanchai T, Kreuzer M and Wicke M (2008). Differences in carcass and meat characteristics between chicken indigenous to northern Thailand (Black-boned and Thai native) and imported extensive breeds (Bresse and Rhode Island red). Poult. Sci. 87: 160-169. 
Kajimoto Y and Rotwein P (1991). Structure of the chicken insulin-like growth factor I gene reveals conserved promoter elements. J. Biol. Chem. 266: 9724-9731.

Khandwala HM, McCutcheon IE, Flyvbjerg A and Friend KE (2000). The effects of insulin-like growth factors on tumorigenesis and neoplastic growth. Endocr. Rev. 21: 215-244.

Li ZH, Li H, Zhang H, Wang SZ, et al. (2006). Identification of a single nucleotide polymorphism of the insulin-like growth factor binding protein 2 gene and its association with growth and body composition traits in the chicken. $J$. Anim. Sci. 84: 2902-2906.

McMurtry JP (1998). Nutritional and developmental roles of insulin-like growth factors in poultry. J. Nutr. 128: 302S-305S.

Pollak MN, Schernhammer ES and Hankinson SE (2004). Insulin-like growth factors and neoplasia. Nat. Rev. Cancer 4: 505-518.

Promwatee N and Duangjinda M (2010). Association of Single Nucleotide Polymorphisms in GHSR, IGF-I, cGH and IGFBP2 Gene with Growth Traits in Thai Native Chickens. In: In 14th AAAP Animal Science Congress, Pingtung, August 23-27, 2010 44-47.

Scanes CG (2009). Perspectives on the endocrinology of poultry growth and metabolism. Gen. Comp. Endocrinol. 163: 24-32.

Scanes CG, Dunnington EA, Buonomo FC, Donoghue DJ, et al. (1989). Plasma concentrations of insulin like growth factors (IGF-)I and $I G F-I I$ in dwarf and normal chickens of high and low weight selected lines. Growth Dev. Aging 53: 151-157.

Wattanachant S, Benjakul S and Ledward DA (2004). Composition, color, and texture of Thai indigenous and broiler chicken muscles. Poult. Sci. 83: 123-128.

Zhou H, Mitchell AD, McMurtry JP, Ashwell CM, et al. (2005). Insulin-like growth factor-I gene polymorphism associations with growth, body composition, skeleton integrity, and metabolic traits in chickens. Poult. Sci. 84: 212-219.

Zhu M and Zhao S (2007). Candidate gene identification approach: progress and challenges. Int. J. Biol. Sci. 3: 420-427. 